\title{
Salacia campestris root bark extract: peroxidase inhibition, antioxidant and antiradical profile
}

\author{
José Carlos Rebuglio Vellosa' ${ }^{1, *}$, Najeh Maissar Khalil' ${ }^{2}$, Vânia Ortega Gutierres ${ }^{4}$, Vânia Aparecida \\ de Freitas Formenton Macedo dos Santos ${ }^{3}$, Maysa Furlan ${ }^{3}$, Iguatemy Lourenço Brunetti ${ }^{4}$, Olga \\ Maria Mascarenhas de Faria Oliveira ${ }^{3, *}$
}

\author{
${ }^{1}$ University Laboratory of Clinical Analysis, Toxicological and Clinical Analysis Department, Paraná State University of Ponta \\ Grossa, ${ }^{2}$ Pharmacy Department, MidWest Paraná State University, ${ }^{3}$ Biochemistry and Technological Chemistry Department, \\ Chemistry Institute, Sao Paulo State University, ${ }^{4}$ Clinical Analysis Department, School of Pharmaceutical Sciences, Sao Paulo \\ State University, ${ }^{5}$ Organic Chemistry Department, Chemistry Institute, Sao Paulo State University
}

\begin{abstract}
Reactive oxygen species (ROS) and free radical species have been implicated in initiating or accompanying many diseases in living organisms; there is thus, a continual need for antioxidants molecules to inactivate ROS/free radicals. Many studies of plants crude extracts have demonstrated free-radical scavenging and antioxidant action. Salacia species have long been used, in several countries, as traditional medicines against certain diseases and for their anti-inflammatory properties. In this study, Salacia campestris Walp (Hippocrateaceae) root bark ethanol extract $(\mathrm{ScEtOH})$ was assessed for its ability to scavenge free radicals and reactive oxygen species; the results were expressed as percentage inhibition of the active species. ScEtOH was efficient against studied species: DPPH radical (obtained inhibition $=30 \%), \mathrm{ABTS}^{\cdot+}\left(\mathrm{IC}_{50}\right.$ $=1.8 \pm 0.8 \mu \mathrm{g} / \mathrm{mL}), \mathrm{HOCl}\left(\mathrm{IC}_{50}=1.7 \pm 0.1 \mu \mathrm{g} / \mathrm{mL}\right), \mathrm{O}_{2}{ }^{-}$(obtained inhibition $=32 \%$ ), and $\mathrm{NO}^{\circ}$ (obtained inhibition $=18 \%$ ). Peroxidase activity inhibition was evaluated through the guaiacol oxidation reaction catalyzed by hemin, HRP and myeloperoxidase (MPO); data showed that ScEtOH at $10 \mu \mathrm{g} / \mathrm{mL}$ led to 54 and $51 \%$ of inhibition, respectively, for the hemin and HRP systems. In the MPO system, ScEtOH promoted a $50 \%$ inhibition at $8.9 \mu \mathrm{g} / \mathrm{mL}$, whereas quercetin, a powerful MPO inhibitor, inhibited this system at $1.35 \mu \mathrm{g} / \mathrm{mL}$.
\end{abstract}

Uniterms: Salacia campestris Walp/antioxidant properties. Hippocrateaceae. Myeloperoxidase. Reactive oxygen species. Antioxidants. Free radicals.

Espécies reativas do oxigênio (ERO) e radicais livres estão relacionados ao início ou à exacerbação de muitas doenças em organismos vivos; existindo portanto uma necessidade contínua por moléculas antioxidantes que inativem as ERO e radicais livres. Muitos estudos com extratos brutos de plantas têm demonstrado propriedades antioxidantes e seqüestradoras de radicais livres. Espécies de Salacia são utilizadas, em muitos países, como remédio tradicional contra certas doenças e por suas propriedades antiinflamatórias. Neste estudo, o extrato bruto etanólico da casca da raiz da Salacia campestris Walp (Hippocrateaceae) foi avaliado quanto à sua habilidade em seqüestrar radicais livres e espécies reativas do oxigênio; os resultados são expressos como porcentagem de inibição das espécies ativas. ScEtOH mostrou-se eficiente frente as espécies estudadas: radical DPPH (inibição obtida $=30 \%), \mathrm{ABTS}^{\cdot+}\left(\mathrm{IC}_{50}=\right.$ $1,8 \pm 0,8 \mu \mathrm{g} / \mathrm{mL}$ ), $\mathrm{HOCl}\left(\mathrm{IC}_{50}=1,7 \pm 0,1 \mu \mathrm{g} / \mathrm{mL}\right.$ ), $\mathrm{O}_{2}{ }^{-}$(inibição obtida $=32 \%$ ), and NO• (inibição obtida =18\%). A inibição da atividade peroxidásica foi avaliada através da oxidação do guaiacol catalisada pela hemina, HRP e mieloperoxidase (MPO); os dados mostram que $10 \mu \mathrm{g} / \mathrm{mL}$ de ScEtOH promovem 54 e $51 \%$ de inibição, respectivamente para os sistemas da hemina e da HRP. No sistema da MPO, ScEtOH promoveu $50 \%$ de inibição na dose de $8,9 \mu \mathrm{g} / \mathrm{mL}$, enquanto a quercetina, um potente inibidor da MPO promoveu tal inibição com $1,35 \mu \mathrm{g} / \mathrm{mL}$.

Unitermos: Salacia campestris Walp/propriedades antioxidantes Hippocrateaceae. Mieloperoxidase. Oxigênio/espécies reativas. Antioxidantes. Radicais livres.

\footnotetext{
*Correspondence: O. M. M. F. Oliveira. Depto. de Bioquímica e Tecnologia Química, Instituto de Química - UNESP, R. Prof. Francisco Degni, s/n.- Quitandinha - 4800-900 - Araraquara - SP, Brasil. E-mail: olgaenzimologia@yahoo.com.br, josevellosa@yahoo.com.br
} 


\section{INTRODUCTION}

The oxidative burst from polymorphonuclear neutrophils $(\mathrm{PMN})$ entail the production of reactive oxygen species (ROS) generated by two key enzymes, NADPH oxidase and myeloperoxidase (MPO). Free radicals may play an important role in the origin of life and in biological evolution, and have beneficial effects in living aerobes. For example, oxygen radicals act critically in signal transduction, gene transcription and regulation of soluble guanylyl cyclase activity in cells (Tepe et al., 2005a). However, free radicals and other relative species can oxidize biomolecules (e.g., protein, amino acids, lipid, and DNA), leading to cell injury and death. Oxidative stress, a disturbance of the oxidant/antioxidant ratio in living aerobic organisms, may be involved in processes such as mutagenesis, carcinogenesis, lipid peroxidation, fragmentation of proteins, and carbohydrate damage (Ferreira, Matsubara, 1997; Babior, 2000). Experimental data have indicated that free radicals play a critical role in a variety of pathological processes, including aging, multiple sclerosis, inflammation, coronary heart and cardiovascular diseases, senile dementia, arthritis and atherosclerosis (Ferreira, Matsubara, 1997; Babior, 2000; Benedì et al., 2004; Vellosa et al., 2007a).

A continual supply of antioxidant molecules is necessary for ROS inactivation. In an effort to prevent or diminish induced ROS damage, investigators have evaluated compounds that prevent their generation and reduce the damage. Recent studies shown that a number of plant products, including polyphenols, flavonoids and terpenes and various plant extracts, exert a free-radical scavenging and an antioxidant action (Corsino et al., 2000; Pereira et al., 2005; Carvalho et al., 2005; Cui et al., 2005; Benedì et al., 2004;). Natural antioxidants obtained from plant extracts have attracted increasing interest, owing to consumer concern about the safety of the synthetic antioxidants in food. Extracts from fruits, vegetables, cereals and their by-products have shown effective antioxidant activity in model biological systems (Tepe et al., 2005b; Sun, Ho, 2005).

Several representatives of the related Hippocrateaceae and Celastraceae families are claimed to be medically useful as antimicrobial, anticancer and antimalarial. Some Salacia species (Hippocrateaceae) have long been used in India, Sri Lanka, and China as traditional medicines for the treatment of rheumatism and skin diseases, and also for their anti-inflammatory properties (Carvalho et al., 2005).

Quinonemethide triterpenes, secondary metabolites restricted to the higher plant families Celastraceae and Hippocrateaceae, have shown a variety of biological activity such as antitumoral, antimicrobial and antimalarial
(Corsino et al., 2000). Carvalho et al. (2005) described the occurrence of several quinonemethide triterpenes (salacin, friedelin, pristimerin, maytenin, $20 \alpha$-hydroxymaytenin and netzahualcoyene) in S. campestris (Hippocrateaceae) root barks and compared their anti-radical properties by their DPPH scavenger potential.

Protection of the living organism against oxidative stress relies not only on endogenous antioxidants, but also on exogenous compounds taken in food and beverages. In view of the therapeutic actions of Salacia species against rheumatism and inflammation, it is important to evaluate the antioxidant and antiradical potential of Salacia campestris Walp. It would also be useful to know if crude extract or isolated compounds from $S$. campestris are able to inhibit ROS generation by peroxidases, mainly MPO.

\section{MATERIALS AND METHODS}

\section{Experimental apparatus and analytical condition}

This study was undertaken in order to assess the antioxidant activity of crude ethanol extract of $S$. campestris root bark ( $\mathrm{ScEtOH})$ by determining its capacity to scavenge free radicals and some reactive oxygen species, and inhibit peroxidase activity from hemin, HRP type VI (horseradish peroxidase; EC 1.11.1.7) and MPO (from polymorphonuclear neutrophils of Rattus norvegicus var. albinus). All assays were done with a HP 8453 Diode Array Spectrophotometer. Various doses of plant extract, uric acid (a natural antioxidant) and trolox (E vitamin analogue) were assayed and their scavenger capacities against oxidant species were calculated as mean values of triplicates assays and expressed as percentage of radical or ROS scavenged ( $\%$ inhibition) calculated for $\mathrm{HOCl}$ assay by Eq.1, and by Eq. 2 for DPPH, $\mathrm{ABTS}^{\circ+}$, NO ${ }^{*}$ assays.

Inhibition (\%) $=\left(1-\left(\begin{array}{l}\mathrm{A}_{0}-\mathrm{A}_{\mathrm{T}} \\ \mathrm{A}_{0}-\mathrm{A}_{1}\end{array}\right)\right) \times 100$

Where: $\mathbf{A}_{0}$ is test absorbance at $412 \mathrm{~nm}$ without $\mathrm{HOCl}$ or sample, $\mathbf{A}_{\mathbf{1}}$ is test absorbance at $412 \mathrm{~nm}$ with $\mathrm{HOCl}$, but no sample and $\mathbf{A}_{\mathbf{T}}$ is test absorbance at $412 \mathrm{~nm}$ with $\mathrm{HOCl}$ and sample.

Inhibition $(\%)=\left(1-\left(\frac{\mathrm{A}_{\text {sample }}}{\mathrm{A}}\right)\right) \times 100$

Eq.2

Where: $\mathbf{A}$ is test absorbance without sample and $\mathbf{A}_{\text {sample }}$ is test absorbance with sample. 


\section{Plant material}

Salacia campestris root barks were identified and supplied by Prof. Dr. Maria Helena de O. Antunes, from Fazenda Canchin at the São Carlos Federal University, São Carlos (SP, Brazil). The voucher specimens (No.2845) are deposited at the Herbarium of Botany Department of the Federal University of São Carlos (UFSCar), São Carlos (SP, Brazil). The bark root (51.20 g) from the specimen was dried over $40^{\circ} \mathrm{C}$ and triturated. After that, the obtained powder was submitted to an ultrasound extraction with ethanol $(300 \mathrm{~mL})$ by 20 minutes in triplicate and concentrating the filtrate under reduced pressure for obtaining an ethanolic crude extract (8.6 g).

\section{Chemicals}

Quercetin, ABTS [2,2'-azinobis(3-ethylbenzothiazoline-6-sulfonic acid)], DTNB [5,5'-dithiobis(2nitrobenzoic acid)], guaiacol, hemin, HRP (horseradish peroxidase), trolox, uric acid, phenazine methosulfate (PMS), NADH, NBT (nitrobluetetrazolium), and DPPH (2,2-diphenyl-1-picrylhydrazyl) were purchased from Sigma Chemicals Co. Griess Reagent was kindly provided by Professor Iracilda Zeppone Carlos (Clinical Immunology Lab. of the School of Pharmaceutical Sciences - UNESP at Araraquara, SP, Brazil). All other reagents were analytical grade and commercially available.

\section{DPPH radical scavenging activity}

DPPH is a free radical that, when dissolved in ethanol, has purple color. Loss of this color indicates radical scavenging activity. Ethanol solutions of $S$. campestris extracts and trolox and aqueous solutions of uric acid at various concentrations were evaluated against $60 \mu \mathrm{M}$ $\mathrm{DPPH}$. The reaction mixture (total volume $1.0 \mathrm{~mL}$ ) was shaken vigorously and allowed to react at room temperature. After 15 min remaining DPPH was determined colorimetrically at $531 \mathrm{~nm}$, using absolute ethanol as a blank (Brand-Williams et al., 1995).

\section{$\mathrm{ABTS}^{*+}$ radical scavenging activity}

Pellegrini et al. (1999) used the $\mathrm{ABTS}^{\cdot+}$ assay to evaluate antioxidant capacity of some fruits extracts using absolute ethanol as diluent. In this paper, ethanol was replaced by sodium phosphate buffer. $\mathrm{ABTS}^{\cdot+}$ was prepared by reacting $5 \mathrm{~mL}$ of $7 \mathrm{mM}$ ABTS aqueous solution with $88 \mu \mathrm{L}$ of $140 \mathrm{mM}$ potassium persulphate (molar ratio $1: 0.35)$ and the mixture allowed to stand in the dark at room temperature for $12-16 \mathrm{~h}$ before use. Prior to assay this ABTS $^{\cdot+}$ stock solution was diluted with $\mathrm{NaH}_{2} \mathrm{PO}_{4} /$ $\mathrm{Na}_{2} \mathrm{HPO}_{4}(100 \mathrm{mM}, \mathrm{pH} 7.0$, diluted 1:10 before use) buffer solution (ratio 1:88) to give an absorbance at $734 \mathrm{~nm}$ of $0.414 \pm 0.013(\mathrm{n}=40)$. One milliliter $\mathrm{ABTS}^{\cdot+}$ was then added to glass test tubes containing various concentrations of each extract and mixed for $15 \mathrm{~s}$. Tubes were incubated for $30 \mathrm{~min}$ and then read at $734 \mathrm{~nm}$.

\section{$\mathrm{HOCl}$ scavenging activity}

TNB (5-thio-2-nitrobenzoic acid) was produced from DTNB, as described by Ching and co-workers (1994). TNB $(80 \mu \mathrm{M})$ is oxidized to DTNB by $\mathrm{HOCl}$ $(22 \mu \mathrm{M})$ causing the absorbance at $412 \mathrm{~nm}$ to fall while DTNB absorbance (325 nm) appeared. Samples were incubated with $\mathrm{HOCl}$ for $5 \mathrm{~min}$ in $\mathrm{NaH}_{2} \mathrm{PO}_{4} / \mathrm{Na}_{2} \mathrm{HPO}_{4}(50 \mathrm{mM}$, $\mathrm{pH}$ 7.0) buffered solution. TNB was then added, following 15 min incubation on $25^{\circ} \mathrm{C}$ (Ching et al., 1994).

\section{Superoxide radical scavenging activity}

Superoxide radicals, produced by NADH and PMS, reduce NBT and produce a formazan compound. The intensity of color is inversely proportional to the antioxidant concentration (Kakkar et al., 1984). The assay was carried out in sodium pyrophosphate buffer $(0.025 \mathrm{M}, \mathrm{pH}$ 8.3) and the mixture contained $25 \mu \mathrm{L}$ of $372 \mu \mathrm{M}$ PMS, $75 \mu \mathrm{L}$ of $600 \mu \mathrm{M}$ NBT, $50 \mu \mathrm{L}$ of $1560 \mu \mathrm{M}$ NADH, plant extract (several volumes) and buffer to complete $1 \mathrm{~mL}$ final volume. Reactions were started by adding NADH. After incubation at $25^{\circ} \mathrm{C}$ for $90 \mathrm{~s}, 100 \mu \mathrm{L}$ of glacial acetic acid and $900 \mu \mathrm{L}$ of sodium pyrophosphate buffer were added. After vigorous homogenization, the color intensity of mixture was measured at $560 \mathrm{~nm}$.

\section{Nitric oxide radical scavenging activity}

For this assay, several volumes of $\operatorname{ScEtOH}(10 \mu \mathrm{g} / \mathrm{mL})$ were added to test tubes with sodium nitroprusside solution $(25 \mathrm{mM})$ to give a final volume of $1 \mathrm{~mL}$, and the tubes were incubated at $25{ }^{\circ} \mathrm{C}$ for $1.5 \mathrm{~h}$. An aliquot $(0.25 \mathrm{~mL})$ of the solution was then withdrawn and diluted with $0.15 \mathrm{~mL}$ Griess Reagent (1\% sulfanilamide in $5 \% \mathrm{H}_{3} \mathrm{PO}_{4}$ and $0.1 \%$ naphthylethylenediamine dihydrochloride). The absorbance of the chromophore, produced during diazotization of the nitrite with sulfanilamide and subsequent coupling with naphthylethylenediamine dihydrochloride, was immediately read at $570 \mathrm{~nm}$. Sodium nitroprusside is known to decompose in aqueous solution at physiological $\mathrm{pH}$, producing $\mathrm{NO}^{\circ}$. Under aerobic conditions, $\mathrm{NO}^{\circ}$ 
reacts with oxygen to produce the stable products nitrate and nitrite, and the nitrite can be determined with Griess reagent. The final absorbance at $570 \mathrm{~nm}$ is diminished by an $\mathrm{NO}^{*}$ scavenger, because less nitrite is produced to form the chromophore (Yen et al., 2001).

\section{Hemin and HRP assays}

We evaluated the effect of $S$. campestris extract $(10,1$ and $0.1 \mu \mathrm{g} / \mathrm{mL})$ on: i) Hemin, prosthetic group of peroxidases; the assay was performed in sodium phosphate buffered saline (PBS) $\mathrm{pH} 7.0,25^{\circ} \mathrm{C}$, using $3 \mathrm{mM}$ hemin, $2.5 \mathrm{mM} \mathrm{H}_{2} \mathrm{O}_{2}$, and $5 \mathrm{mM}$ guaiacol; ii) $\mathrm{HRP}$, an important and well studied peroxidase used as a model for peroxidase inhibition studies; we used Dulbecco's phosphate buffered saline (PBS-D), at $37{ }^{\circ} \mathrm{C}, 7 \mathrm{nM}$ HRP, $2 \mathrm{mM}$ guaiacol and $0.1 \mathrm{mM} \mathrm{H}_{2} \mathrm{O}_{2}$ which initiated the reaction, followed for $1 \mathrm{~min}$ at $470 \mathrm{~nm}$. The kinetic constant $\mathrm{v}_{0}$ was determined by graphical analysis. All reactions were monitored in the presence of the $S$. campestris extract $(10,1$ and $0.1 \mu \mathrm{g} / \mathrm{mL})$ and in its absence. Quercetin, a MPO inhibitor (Pincemail et al., 1988) was used as a peroxidasic inhibitor pattern.

\section{Myeloperoxidase (MPO) assay}

Reactions with MPO were carried out by guaiacol oxidation, with several concentrations of $S$. campestris extract, in PBS buffer $\mathrm{pH}$ 7.0. The absorbance rate was followed at $470 \mathrm{~nm}$. The final concentrations in the reaction mixture were $20 \mathrm{mM}$ guaiacol and $0.2 \mathrm{mM} \mathrm{H}_{2} \mathrm{O}_{2}$ plus $75 \mathrm{mU}$ MPO. In this system MPO inhibition from ScEtOH and quercetin was evaluated.

\section{MPO extraction from PMN}

These procedures were approved by the UNESPSchool of Pharmaceutical Sciences Ethical Committee (process 09/2005). Neutrophils (PMN) were isolated according to Paino et al. (2005). PMN were obtained from 6 male adults (100-160 grams) Rattus norvegicus var. albinus. Each rat was intraperitoneally inoculated with 5 $\mathrm{mL}$ of $1 \%$ oyster glycogen in $0.85 \% \mathrm{NaCl}$. The animal was sacrificed $12 \mathrm{~h}$ later and its peritoneal cavity washed with $20 \mathrm{~mL}$ PBS-D buffer (calcium free) to obtain a suspension of neutrophils. This was centrifuged at $200 \mathrm{xg}$, for $3 \mathrm{~min}$. The sediment was washed twice with PBS, then resuspended in $500 \mu \mathrm{L}$ of this buffer, and kept at $-20{ }^{\circ} \mathrm{C}$ for $12 \mathrm{~h}$. After cell rupture and centrifuging at $200 \mathrm{~g}$ a crude extract containing MPO was obtained. MPO was determined by assaying guaiacol oxidation in PBS buffer at $\mathrm{pH}$ 7.0. The reaction was followed at $470 \mathrm{~nm}$, with $100 \mathrm{mM}$ guaiacol and $0.5 \mathrm{mM} \mathrm{H}_{2} \mathrm{O}_{2}$ at $25^{\circ} \mathrm{C}$. The MPO activity $(\mathrm{U} / \mathrm{mL})$ was defined by eq. 3 .

Activity $(\mathrm{U} / \mathrm{mL})=\frac{\left(A_{470 \mathrm{~nm}} \text { at } 1 \text { minute }-A_{470 \mathrm{~nm}} \text { at } 0 \text { minute) } x \text { total volume }(\mathrm{mL})\right.}{(\text { Path length) } x \text { crude extract volume }(\mathrm{mL})}$

\section{RESULTS AND DISCUSSION}

DPPH is a stable free radical that can accept an electron or hydrogen radical to become a stable diamagnetic molecule; because of its odd electron, in the ethanol solution shows a strong absorption band at 531 $\mathrm{nm}$ (Brand-Williams et al., 1995). As DPPH reacts with suitable reducing agents, this electron becomes paired off causing a color change from purple to yellow and the solution loses color stoichiometrically with the number of electrons taken up. This reactivity has been widely used to test either the ability of diverse compounds to act as free radical scavengers or the antioxidant activity of plant extracts (Soares et al., 1997). DPPH reduction was estimated from the bleaching of the radical solution (decay of absorbance at $531 \mathrm{~nm}$ ) in the presence of the extracts and substances assayed. Fig. 1 shows dose-response curves obtained DPPH scavenging using trolox, uric acid or ScEtOH. Whereas the ethanol extract and uric acid did not promote $50 \%$ inhibition within the assayed doses, trolox was shown to be a good free radical scavenger with an $\mathrm{IC}_{50}$ of $3.3 \pm 0.4 \mu \mathrm{g} / \mathrm{mL}$, raising $94 \%$ inhibition at about $13 \mu \mathrm{g} / \mathrm{mL}$. According to these data, ScEtOH was a slightly

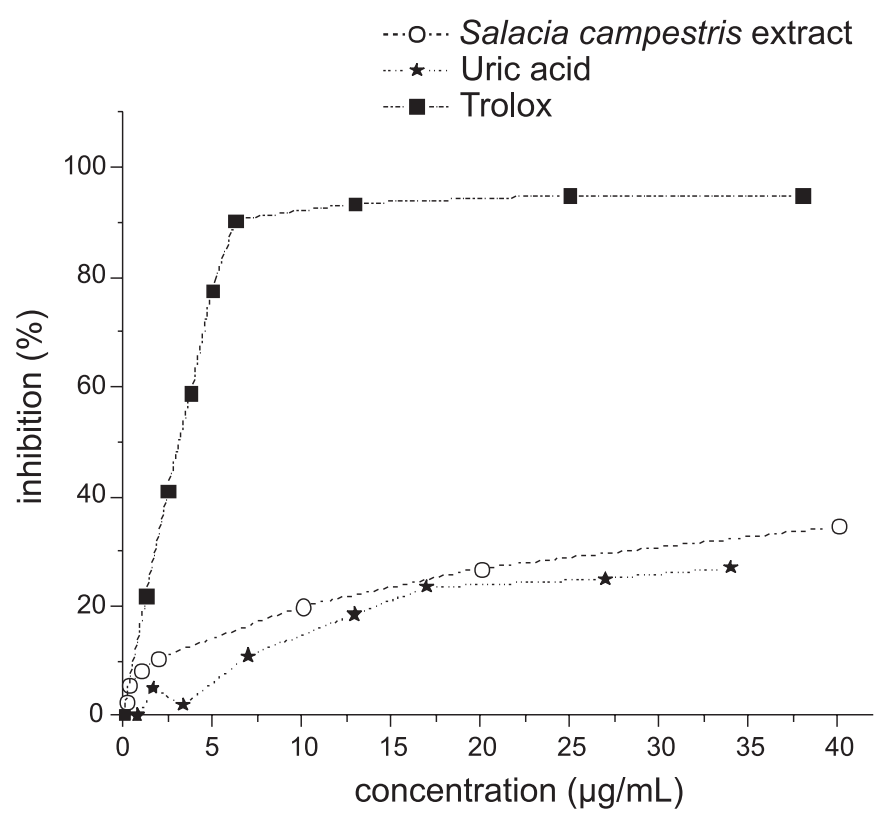

FIGURE 1 - DPPH radical $(60 \mu \mathrm{M})$ scavenger action by $S$. campestris extract, uric acid and trolox. The reactions were made in ethanol, at $25^{\circ} \mathrm{C}$, and incubated by $15 \mathrm{~min}$. 
better DPPH scavenger than uric acid. The S. campestris ethanolic extract inhibition $(30 \%$ in $40 \mu \mathrm{g} / \mathrm{mL})$ was similar to the one observed to the ethanolic extract from Maytenus aquifolium in a previous study (Vellosa et al., 2007b).

The ABTS ${ }^{\cdot+}$ assay has been used to screen the relative radical-scavenging capacities of flavonoids and phenolics, which act as electron- or H-donating agent or plant extracts that contains these substances (Pellegrini et al., 1999). The green cation radical $\mathrm{ABTS}^{\cdot+}$ has absorbance peaks at 630, 734 and $812 \mathrm{~nm}$. On interaction with antioxidants the radical is reduced, suppressing the absorbance of the green radical cation in a dose-dependent way. From the data in Fig. 2, the samples can be classified in order of descending scavenging power, by comparing $\mathrm{IC}_{50}$ values (in brackets): trolox $(0.7 \pm 0.04 \mu \mathrm{g} / \mathrm{mL})>$ uric acid $(1.2 \pm 0.06 \mu \mathrm{g} / \mathrm{mL})>\operatorname{ScEtOH}(1.8 \pm 0.08 \mu \mathrm{g} / \mathrm{mL})$. Vellosa et al. (2006) and Oliveira et al. (2007) observed good DPPH scavenger action respectively to Maytenus ilicifolia $\left(\mathrm{IC}_{50}=2 \mu \mathrm{g} / \mathrm{mL}\right)$ and Agaricus Blazei $\left(\mathrm{IC}_{50}=23 \mu \mathrm{g} / \mathrm{mL}\right)$. The $S$. campestris ethanolic extract is so efficient scavenger of $\mathrm{ABTS}^{\cdot+}$ as it was M. ilicifolia ethanolic extract and more efficient than $A$. blazei ethanolic extract. The $S$. campestris ethanolic extract has a bigger scavenger capacity than Maytenus aquifolium $\left(\mathrm{IC}_{50}=4 \mu \mathrm{g} / \mathrm{mL}\right)$ (Vellosa et al., 2007b).

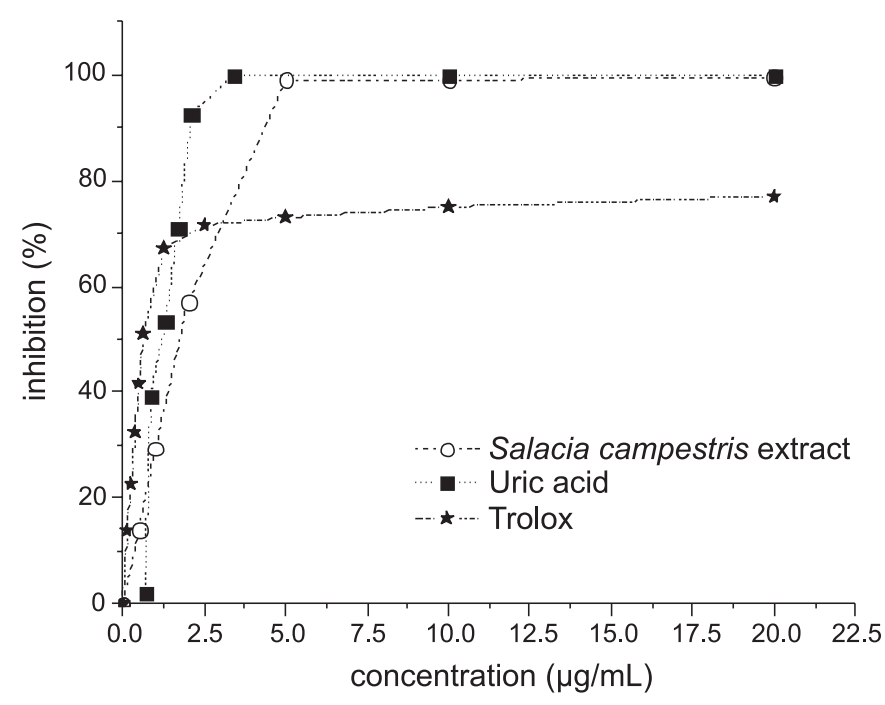

FIGURE 2 - ABTS $^{\cdot+}$ radical $(55 \mu \mathrm{M})$ Scavenger action by $S$. campestris extract, uric acid and trolox. The reactions were made in $10 \mathrm{mM}$ sodium phosphate buffer, $\mathrm{pH} 7.0,25^{\circ} \mathrm{C}$, and incubated by $30 \mathrm{~min}$.

In biological systems, hypochlorous acid is the most toxic and abundant oxidant agent produced by PMN (Lapenna, Cuccurollo, 1996; Vellosa et al., 2007c). It can attack important biological molecules and generate other harmful ROS (Weiss, 1989; Eaton, 1993). This oxidant specie reacts with ammonia produced by Helicobacter pylori in human stomach to produce the microbicide monochloramine, which is also related to stomach injury observed in gastric ulcers (Lapenna, Cuccurollo, 1996). Hence, it is important to discover drugs and plant extracts that are able to fight $\mathrm{HOCl}$. Here, we evaluated the potential of $\mathrm{ScEtOH}$ to scavenge $\mathrm{HOCl}$, in a comparative study with trolox and uric acid. From the results in Fig. 3, the $\mathrm{IC}_{50}$ values can be obtained and used to rank the samples as HOCl scavengers: uric acid $(0.3 \pm 0.03 \mu \mathrm{g} / \mathrm{mL})>\mathrm{ScEtOH}$ $(1.7 \pm 0.1 \mu \mathrm{g} / \mathrm{mL})>$ trolox $(3.1 \pm 0.3 \mu \mathrm{g} / \mathrm{mL})$. These values were equal to those ones obtained to Maytenus species in previous studies (Vellosa et al., 2006, 2007b). The results are very encouraging, because $S$. campestris leaves, like Maytenus ilicifolia and Maytenus aquifolium, are currently used in Brazilian folk medicine against gastric ulcers and any gastric protection obtained may be explained, at least partly, by scavenging $\mathrm{HOCl}$.

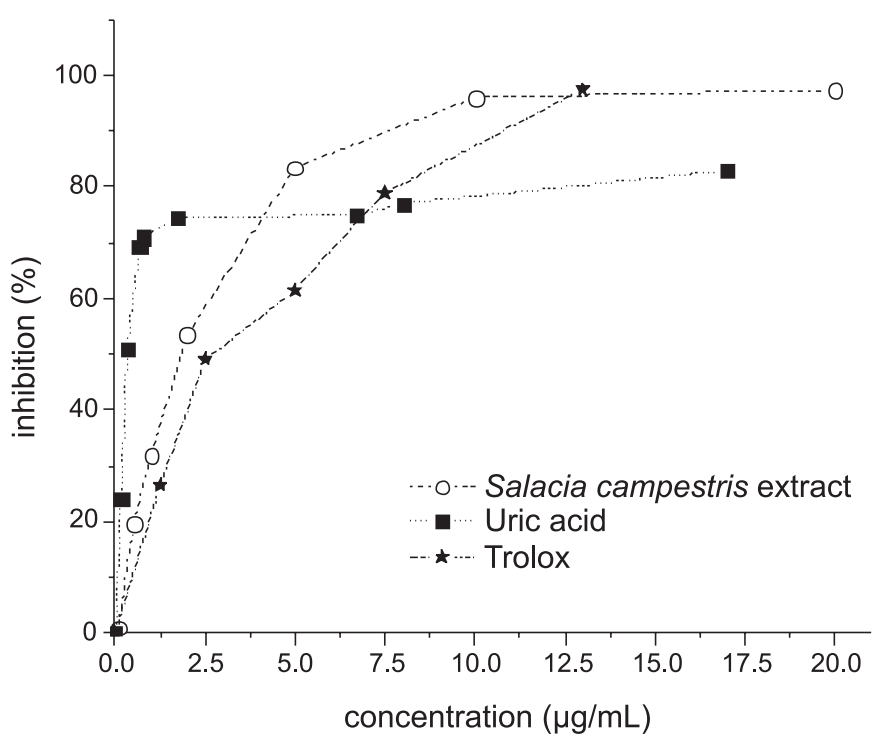

FIGURE 3 - HOCl $(22 \mu \mathrm{M})$ Scavenger action by S. campestris extract, uric acid and trolox. The reactions were made in $50 \mathrm{mM}$ sodium phosphate buffer, $\mathrm{pH} 7.0,25{ }^{\circ} \mathrm{C}$, and incubated by $15 \mathrm{~min}$.

ScEtOH action over superoxide anion was evaluated by a non-enzymatic method of generating superoxide by reacting phenazine methosulfate with NADH. The superoxide is stained by NBT. We used this system to evaluate if the samples tested are able to antagonize superoxide anion in vitro. It is important to note that in this method, NBT must be in excess to evaluate the real potential of samples to scavenge the superoxide anion. Any superoxide scavenger potential found for $\mathrm{ScEtOH}$ could be expected to contribute to a possible protective action in various tissues, including stomach. From Figure 4, it can be concluded that 
S. campestris ethanol extract is much better than either uric acid or trolox at scavenging superoxide radical anion.

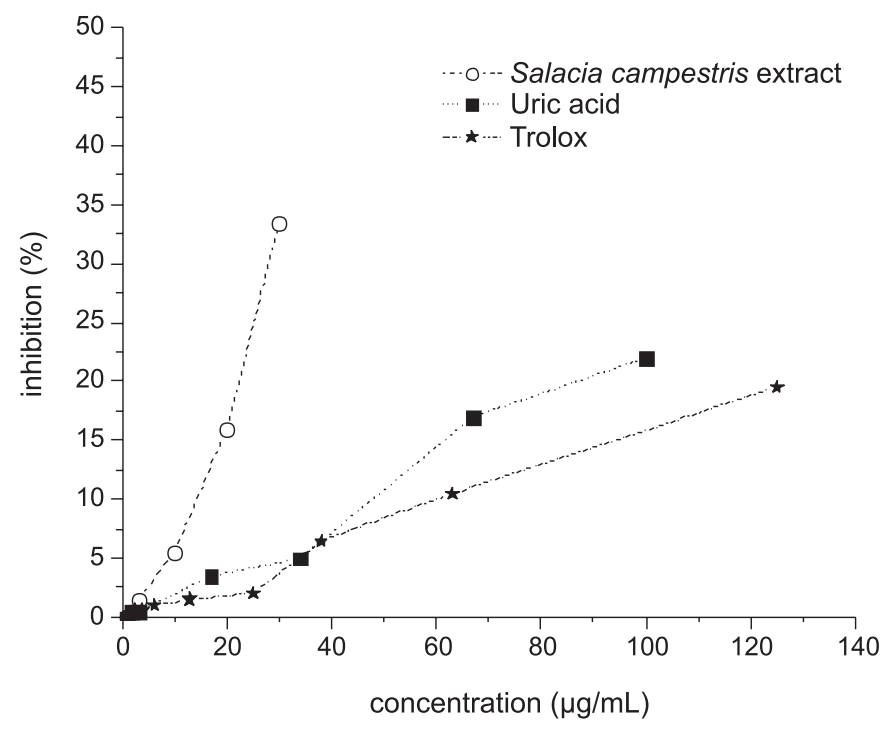

FIGURE 4 - Superoxide anion radical Scavenger action by $S$. campestris extract, uric acid and trolox. The reactions were made in $25 \mathrm{mM}$ sodium pyrophosphate buffer, $\mathrm{pH} 8.3,25^{\circ} \mathrm{C}$, and incubated by $90 \mathrm{~s}$.

Recent studies have shown that reactive nitrogen intermediates, such as nitric oxide (NO), peroxynitrite $\left(\mathrm{ONOO}^{\circ}\right)$ and nitrogen dioxide $\left(\mathrm{NO}_{2}\right)$, also play an important part in the inflammatory process and possibly in carcinogenesis (Yen et al., 2001). We constructed an analytical curve with sodium nitrite to calculate the nitric oxide level in the sodium nitroprusside method described above. In this method, using sodium nitroprusside as a source of nitric oxide, control tubes (without scavengers) had absorbance values of $0.428 \pm 0.02(\mathrm{n}=40)$, representing about $21 \mu \mathrm{M} \mathrm{NO}^{*}$ (Figure 5). We evaluated the potential of trolox, uric acid and $\mathrm{ScEtOH}$ as nitric oxide scavengers (Figure 6). Note that trolox is unable to scavenge nitric oxide. The data show that ScEtOH and uric acid had similar scavenging action against the nitric oxide radical.

ScEtOH is effective over the evaluated systems - DPPH radical (obtained inhibition $=30 \%$ ), ABTS $^{\cdot+}$ $\left(\mathrm{IC}_{50}=1.8 \pm 0.8 \mu \mathrm{g} / \mathrm{mL}\right), \mathrm{HOCl}\left(\mathrm{IC}_{50}=1.7 \pm 0.1 \mu \mathrm{g} / \mathrm{mL}\right)$, $\mathrm{O}_{2}{ }^{-}$(obtained inhibition $=32 \%$ ), and $\mathrm{NO}^{\circ}$ (obtained inhibition $=18 \%$ ). According to results previously published by Vellosa et al. (2007 B), ScEtOH have a similar potential to Maytenus aquifolium on scavenging these species (exception against $\mathrm{ABTS}^{\cdot+}$ ) - DPPH radical (obtained inhibition $=36 \%), \mathrm{ABTS}^{+}\left(\mathrm{IC}_{50}=3.6 \pm 0.3 \mu \mathrm{g} / \mathrm{mL}\right), \mathrm{HOCl}$ $\left(\mathrm{IC}_{50}=2.0 \pm 0.1 \mu \mathrm{g} / \mathrm{mL}\right), \mathrm{O}_{2}{ }^{-}$(obtained inhibition $\left.=36 \%\right)$, and $\mathrm{NO}^{\circ}$ (obtained inhibition $=18 \%$ ). In previous studies Carvalho et al. (2005) and Corsino et al. (2000) had isola-

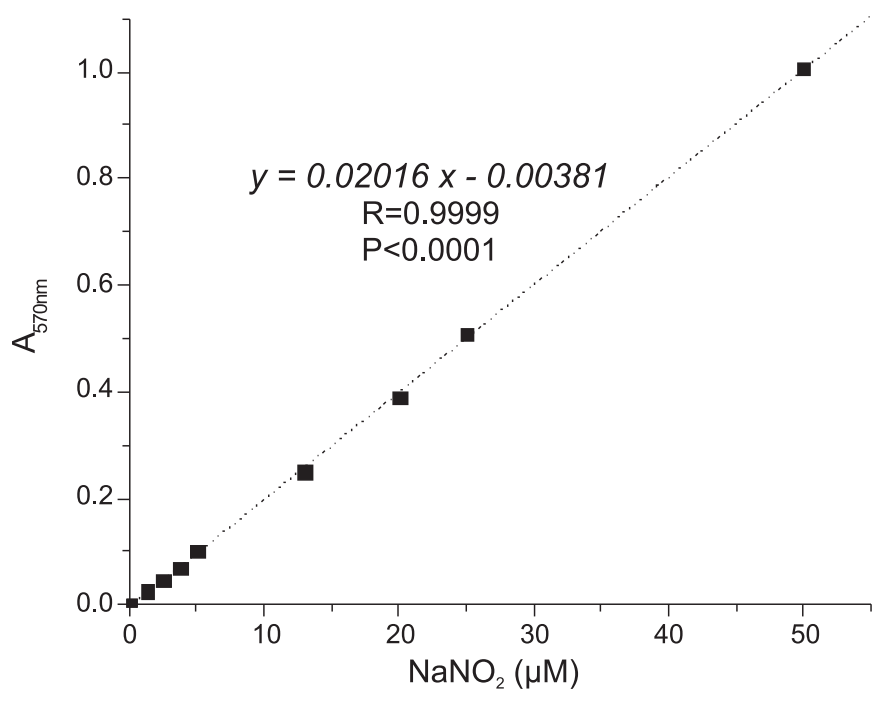

FIGURE 5 - Analytical curve of sodium nitrite developed by Griess Reagent. The reactions were made in $50 \mathrm{mM}$ sodium phosphate buffer, $\mathrm{pH} 7.0,25^{\circ} \mathrm{C}$, and incubated by $15 \mathrm{~min}$.

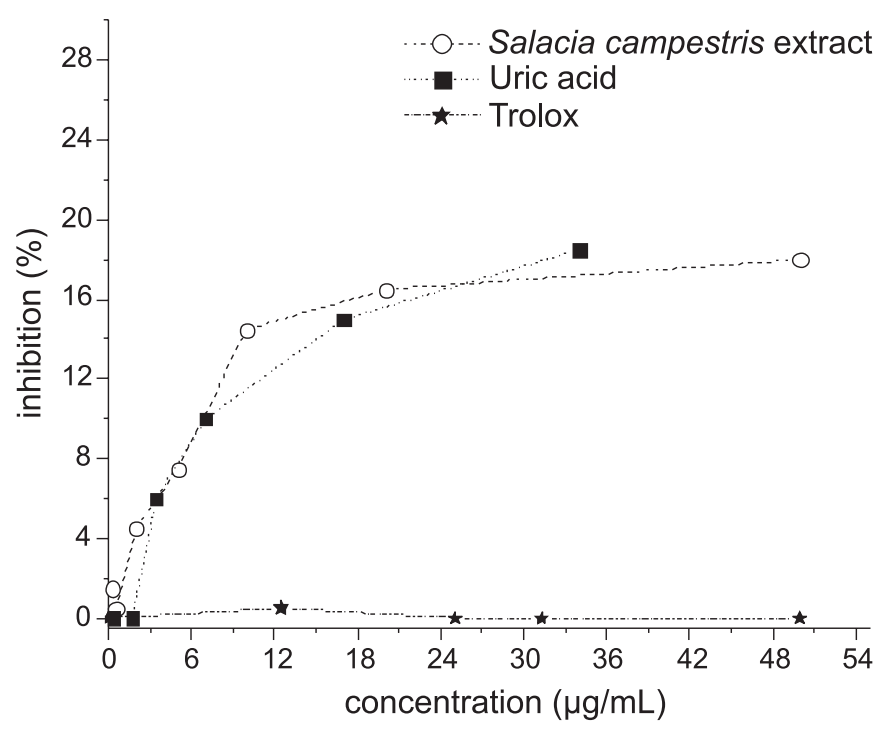

FIGURE 6 - Nitric oxide Scavenger action by S. campestris extract, uric acid and trolox. The reactions were made in $50 \mathrm{mM}$ sodium phosphate buffer, $\mathrm{pH} 7.0,25^{\circ} \mathrm{C}$, and incubated by 90 min before reaction with Griess Reagent.

ted from $S$. campestris some quinonepethides triterpenoids that presented antioxidant properties that may be related to the results observed in this paper. However, due the hydrophobic nature of these compounds [(Carvalho et al. (2005) have extracted these compounds using $\mathrm{CH}_{2} \mathrm{Cl}_{2}$ as solvent, and Corsino et al. (2000) had used hexane], quinonemethides triterpenes must be at low levels in the evaluated ethanolic extract. The results observed must be explicated mainly by the hydrophilic flavonoids extracted by ethanol as solvent.

Peroxidases are heme-containing enzymes that use 
$\mathrm{H}_{2} \mathrm{O}_{2}$ to oxidize a variety of biomolecules and xenobiotics. The heme in the native enzyme is usually ferriprotoporphyrin IX, with four pyrrole nitrogens bound to the Fe(III). The fifth coordination position on the proximal side of the heme is usually occupied by the imidazole side chain of a histidine residue. The sixth coordination position is vacant in the native enzyme on the distal side of the heme. Plant peroxidases, e.g. horseradish peroxidase, consist of about 300 amino acids and a non-covalently bound heme, whereas mammalian peroxidases are much larger (576-738 amino acids) and the heme is covalently bound (O'Brien, 2000). In this paper, we evaluated the effect of quercetin, a powerful MPO inhibitor (Pincemail et al., 1988), and ScEtOH on hemin (free heme from peroxidases) and HRP activity. The results are showed in Tables 1 and 2. At the highest concentration $(10 \mu \mathrm{g} / \mathrm{mL}) \mathrm{ScEtOH}$ inhibited guaiacol oxidation by hemin and by HRP. So, it is possible that the mechanism of peroxidase inhibition by $\mathrm{ScEtOH}$ is related to an action over the enzymes prosthetic group.

MPO is an important peroxidase from neutrophils that use $\mathrm{H}_{2} \mathrm{O}_{2}$ and chloride ions to catalyze the production of the reactive and cytotoxic oxidant hypochlorous

TABLE 1 - Guaiacol $(5 \mathrm{mM}) / \mathrm{H}_{2} \mathrm{O}_{2}(2.5 \mathrm{mM})$ oxidation by hemin $(3 \mu \mathrm{M})$ in presence and absence of $S$. campestris ethanolic extract or quercetin; $\mathrm{v}_{0}$ values - mean $\pm \mathrm{SD}(\mathrm{p}<0.05)$. The reactions were made in $50 \mathrm{mM}$ sodium phosphate buffer, $\mathrm{pH}$ $7.0,25^{\circ} \mathrm{C}$, and incubated by $60 \mathrm{~s}$

\begin{tabular}{lccc}
\hline Sample & \multicolumn{3}{c}{$\mathrm{v}_{0}\left(1.10^{-4} \mathrm{~s}^{-1}\right)$} \\
\hline $\begin{array}{l}\text { Control (no } \\
\text { sample) }\end{array}$ & $54 \pm 7$ & \\
\hline $\begin{array}{l}\text { S. campestris } \\
\text { extract }\end{array}$ & $23 \pm 2$ & $56 \pm 7$ & $51 \pm 1$ \\
\hline quercetin & $3 \pm 1$ & $35 \pm 4$ & $52 \pm 3$ \\
\hline
\end{tabular}

TABLE 2 - Guaiacol $(2 \mathrm{mM}) / \mathrm{H}_{2} \mathrm{O}_{2}(0.1 \mathrm{mM})$ oxidation by $\mathrm{HRP}(7$ $\mathrm{nM}$ ) in presence and absence of $S$. campestris ethanolic extract or quercetin; $\mathrm{v}_{0}$ values - mean $\pm \mathrm{SD}(\mathrm{p}<0.05)$. The reactions were made in $50 \mathrm{mM}$ sodium phosphate buffer, $\mathrm{pH} 7.0,37^{\circ} \mathrm{C}$, and incubated by $60 \mathrm{~s}$

\begin{tabular}{|c|c|c|c|}
\hline \multirow{3}{*}{$\begin{array}{l}\text { Sample } \\
\text { Control (no } \\
\text { sample) }\end{array}$} & \multicolumn{3}{|c|}{$\mathrm{v}_{0}\left(1.10^{-4} \mathrm{~s}^{-1}\right)$} \\
\hline & \multicolumn{3}{|c|}{$144 \pm 10$} \\
\hline & $10 \mu \mathrm{g} / \mathrm{mL}$ & $1 \mu \mathrm{g} / \mathrm{mL}$ & $0.1 \mu \mathrm{g} / \mathrm{mL}$ \\
\hline $\begin{array}{l}\text { S. campestris } \\
\text { extract }\end{array}$ & $70 \pm 10$ & $145 \pm 7$ & $135 \pm 7$ \\
\hline quercetin & $15 \pm 2$ & $129 \pm 2$ & $138 \pm 9$ \\
\hline
\end{tabular}

acid (Jerlich et al., 2000). Effects of ScEtOH and quercetin on MPO inhibition were evaluated by guaiacol oxidation method. ScEtOH promoted a $50 \%$ inhibition at $8.9 \mu \mathrm{g} / \mathrm{mL}$ whereas quercetin (Pincemail et al., 1988) inhibited by $50 \%$ at $1.35 \mu \mathrm{g} / \mathrm{mL}$, both responses being clearly dose-dependent (Figure 7). Quercetin and ScEtOH were able to inhibit guaiacol oxidation by peroxidases (MPO and HRP) and their prostetic group, where quercetin was a more efficient inhibitor. The inhibition observed by the extract may be related to its flavonoids contends and further studies must clarify which flavonoids are able to act as MPO inhibitor and what would be their potential compared to quercetin, a well known flavonoid.

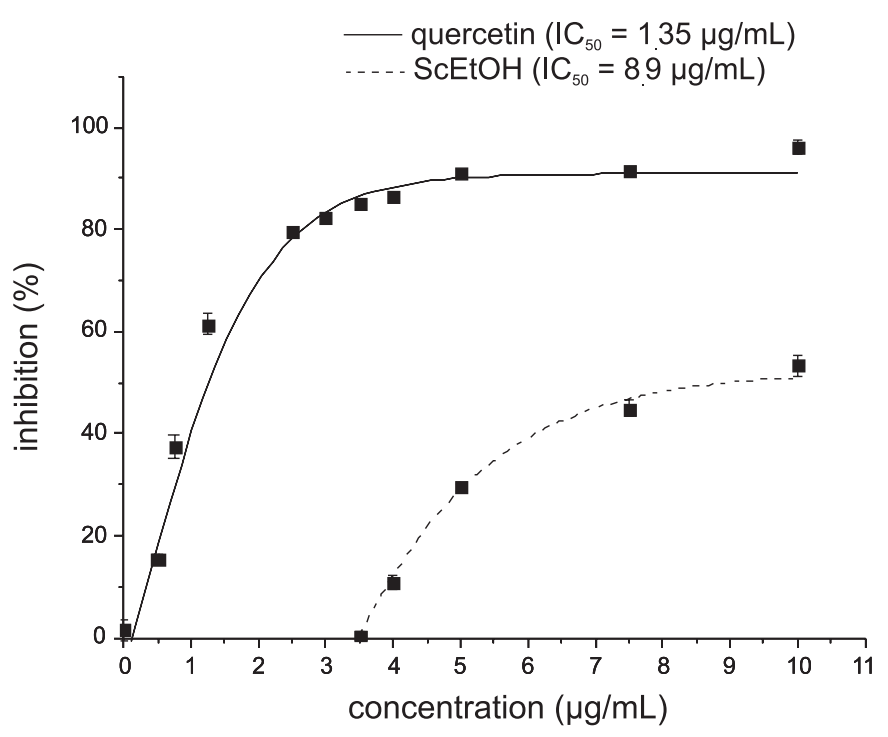

FIGURE 7 - Myeloperoxidase ( $75 \mathrm{mU})$ inhibition, by quercetin and $\mathrm{ScEtOH}$, in a system with $\mathrm{H}_{2} \mathrm{O}_{2}(0.2 \mathrm{mM})$ and guaiacol $(20 \mathrm{mM})$ The reactions were made in $50 \mathrm{mM}$ sodium phosphate buffer, $\mathrm{pH} 7.0,25^{\circ} \mathrm{C}$, and incubated by $60 \mathrm{~s}$.

\section{CONCLUSION}

We demonstrated that $S$. campestris ethanol extract was able to scavenge various oxidant and radical species and inhibit myeloperoxidase, an enzyme involved in many physiological and pathological conditions. We conclude that ScEtOH is efficient against several species assayed. The results provide useful pharmacological information related to free radicals and oxidant species. It is possible that the use of this plant to treat certain pathologies could prevent or fight tissue damage when this involves an established oxidative stress. Of course, further studies are necessary, including: i) isolation and characterization of active compounds from this plant; ii) in vivo studies of biological properties that confirm the possibility suggested 
here; and iii) toxicological studies to evaluate the safety of this plant as a medicinal agent.

\section{ACKNOWLEDGEMENTS}

This work was supported by grants provided by FAPESP. Maysa Furlan is grateful to CNPq for research fellowship. José Carlos R. Vellosa and Vânia A. F. Formenton are grateful to CAPES and CNPq, respectively, for scholarship.

\section{REFERENCES}

BABIOR, B.M. Phagocytes and Oxidative Stress. Am. J. Med., v.109, p.33-44, 2000.

BENEDÍ, J.; ARROYO, R.; ROMERO, C.; MARTÍNARAGON, S.; VILLAR, A.M. Antioxidant properties and protective effects of standardized extract of Hypericum perforatum on hydrogen peroxide-induced oxidative damage in PC12cells. Life Sci., v.75, p.1263-1276, 2004.

BRAND-WILLIAMS, W.; CUVELIER, M.E.; BERSET, C. Use of free radical method to evaluate antioxidant activity. Lebensm. Wiss. Technol., v.28, p.25-30, 1995.

CARVALHO, P.R.F.; SILVA, D.H.S.; BOLZANI, V.S.; FURLAN, M. Antioxidant Quinonemethide Triterpenes from Salacia campestris. Chem. Biodivers., v.2, p.367372, 2005.

CHING, T.; JONG, J.; BAST, A. A method for screening hypochlorous acid scavengers by inhibition of the oxidation of 5-thio-2-nitrobenzoic acid: application to anti-asthmatic drugs. Anal. Biochem., v.218, p.377-381, 1994.

CORSINO, J.; CARVALHO, P.R.F.; KATO, M.J.; LATORRE, L.R.; OLIVEIRA, O.M.M.F.; ARAÚJO, A.R.; BOLZANI, V.S.; FRANÇA, S.C.; PEREIRA, A.M.S.; FURLAN, M. Biosynthesis of friedelane and quinonemethide triterpenoids is compartmentalized in Maytenus aquifolium and Salacia campestris. Phytochemistry, v.55, p.741-748, 2000.

CUI, Y.; KIM, D.S.; PARK, K.C. Antioxidant effect of Innotus obliquus. J. Ethnopharmacol., v.96, p.79-85, 2005.

EATON, J. W. Defenses against hypochlorous acid: parrying the neutrophil's rapier thrust. J. Lab. Clin. Méd., v.121, p.197-198, 1993.
JERLICH, A.; FRITZ, G.; KHARRAZI, H.; HAMMEL, M.; TSCHABUSCHNIG, S.; GLATTER, O.; SCHAUR, R.J. Comparison of $\mathrm{HOCl}$ traps with myeloperoxidase inhibitors in prevention of low density lipoprotein oxidation. Biochim. Biophys. Acta, v.1481, p.109-118, 2000.

KAKKAR, P.; DAS, B.; VISWANATHAN, P. N. A modified spectrophotometric assay of superoxide dismutase. Indian J. Biochem. Biophys., v.21, p.130-132, 1984.

KIOKIAS, S.; GORDON, M.H. Antioxidant properties of annatto carotenoids. Food Chem., v.83, p.523-529, 2003.

LAPENNA, D.; CUCCUROLLO, F. Hypochlorous acid and its pharmacological antagonism: an update picture. Gen. Pharmacol., v.27, p.1145-1147, 1996.

OLIVEIRA O.M.M.F., VELLOSA J.C.R., FERNANDES A.S., BUFFA-FILHO W., HAKIME-SILVA R.A., FURLAN M., BRUNETTI I.L. Antioxidant activity of Agaricus blazei. Fitoterapia, v. 78, p.263-264, 2007.

O`BRIEN, P.J. Peroxidases. Chem. Biol. Interact., v.129, p.113139, 2000.

PAINO I.M.M., XIMENES V.F., FONSECA L.M. DA, KANEGAE M.P.P., KHALIL N.M., BRUNETTI I.L. Effect of therapeutic plasma concentrations of non-steroidal antiinflammatory drugs on the production of reactive oxygen species by activated rat neutrophils. Braz. J. Med. Biol. Res., v.38, p.543-551, 2005.

PELLEGRINI, N.; RE, R.; YANG, M.; EVANS, C. R. Screening of dietary carotenoids and carotenoid-rich fruit extracts for antioxidant activities applying $2,2^{2}$ '-azinobis(3ethylenebenzothiazoline-6 sulfonic acid radical cation decolorization assay. Methods Enzymol., v.299, p.379-389, 1999.

PEREIRA, A.M.S.; JANUÁRIO, A.H.; QUEIROZ, M.E.E.; BIONDO,R.; FRANÇA, S.C. Evaluation of Maytenus aquifolia Mart. and Maytenus ilicifolia Mart. chemotypes for tannins, total phenols and triterpenes. Rev. Bras. Pl. Med., v.8, p.13-17, 2005.

PINCEMAIL, J.; DEBY, C.; THIRION, A., DE BRUYNDISTER, M.; GOUTIER, R. Human myeloperoxidase activity is inhibited in vitro by quercetin. Comparison with three related compounds. Experientia, v.44, p.450-453, 1988. 
SOARES, J.R.; DINIS, T.C.; CUNHA, A.P.; ALMEIDA, L.M. Antioxidant activities of some extracts of Thymus zygis. Free Radic. Res., v.26, p.469-478, 1997.

SUN, T.; HO, C.T. Antioxidant activities of buckwheat extracts. Food Chem., v.90, p.743-749, 2005.

TEPE, B.; SOKMEN, M.; AKPULAT, A.; DAFERERA, D.; POLISSIOU, M.; SOKMEN, A. Antioxidative activity of the essential oils of Thymus sipyleus subsp. sipyleus var. sipyleus and Thymus sipyleus subsp. sipyleus var. rosulans. J. Food Eng., v.66, p.447-454, 2005a.

TEPE, B.; DAFERERA, D.; SOKMEN, A.; SOKMEN, M.; POLISSIOU, M. Antimicrobial and antioxidant activities of the essential oil and various extracts of Salacia tomentosa Miller (Lamiaceae). Food Chem., v.90, p.333-340, 2005 b.

VELLOSA, J.C.R.; BARBOSA, V.F.; OLIVEIRA, O.M.M.F. Pesquisa de produtos naturais: plantas e radicais livres. REF, v.4, p.119-130, 2007a.
VELLOSA, J.C.R; BARBOSA, V.F.; KHALIL, N.M.; SANTOS, V.A F. F. M..; FURLAN; M.; BRUNETTI, I.L.; OLIVEIRA, O.M.M.F. Profile of Maytenus aquifolium action over free radicals and reactive oxygen species. Rev. Bras. Cienc. Farm., v. 43, p. 447-453, 2007 b.

VELLOSA, J.C.R., KHALIL, N.M., FONSECA, L.M. BRUNETTI, I.L.; OLIVEIRA, O.M.M.F. Does cotinine act over reactive oxygen species and peroxidases?. Eclet. Quim., v.32, p.65-70, 2007c.

VELLOSA, J.C.R; KHALIL, N.M.; FORMENTON, V.A.; XIMENES, V.F.; FONSECA, L.M.; FURLAN; M.; BRUNETTI, I.L.; OLIVEIRA, O.M.M.F. Antioxidant activity of Maytenus ilicifolia root bark. Fitoterapia, v.77, p.243-244, 2006.

WEISS, S. J. Tissue destruction by neutrophils. N. Engl. J. Med., v. 320, p. 365-376, 1989.

YEN, G. C.; LAI, H. H.; CHOU, H. Y. Nitric oxide scavenging and antioxidant effects of Uraria crinita root. Food Chem., v. 74, p. 471-478, 2001.

Recebido para publicação em 18 de dezembro de 2007. Aceito para publicação em 10 de novembro de 2008. 